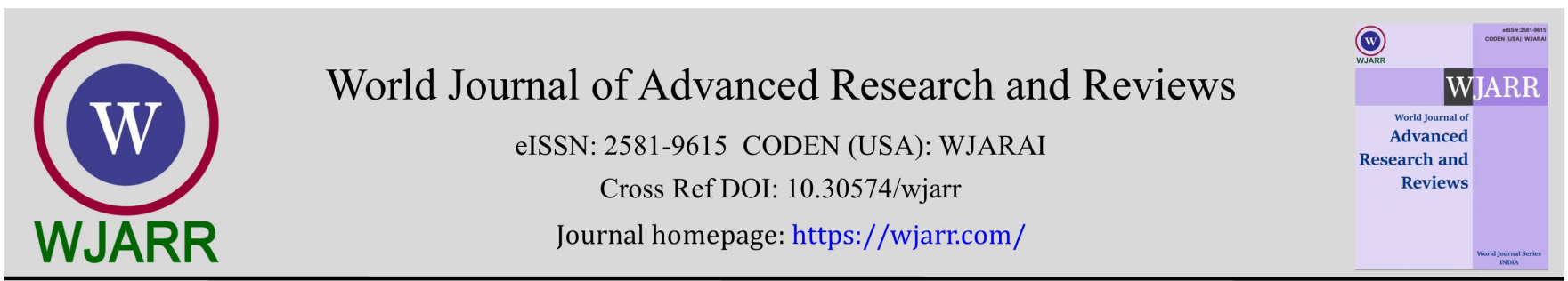

(RESEARCH ARTICLE)

Check for updates

\title{
Change of Ba concentration by species and organ in several fruits grown in city centers
}

\author{
Halil Baris Ozel $1{ }^{*}$, Mesut Sen ${ }^{2}$ and Hakan Sevik ${ }^{3}$ \\ ${ }^{1}$ Bartin University; Faculty of Forestry; Forest Engineering Department, Bartin, Türkiye. \\ ${ }^{2}$ Bartin University; Graduate School; Forest Engineering Department, Bartin, Türkiye. \\ ${ }^{3}$ Kastamonu University; Faculty of Engineering and Architecture; Environmental Engineering Department, Kastamonu, \\ Türkiye.
}

World Journal of Advanced Research and Reviews, 2021, 12(03), 143-150

Publication history: Received on 03 November 2021; revised on 06 December 2021; accepted on 08 December 2021

Article DOI: https://doi.org/10.30574/wjarr.2021.12.3.0681

\begin{abstract}
Heavy metals are elements that are very harmful to human and environmental health. Heavy metal concentration in the fruits grown in city centers can reach very high levels and consuming these fruits as food causes a direct intake of heavy metals, which these fruits contain, into a human body and can pose a significant health risk. All the compounds of barium (Ba), which is one of the most dangerous heavy metals, are toxic. Thus, determining the Ba concentration in plants, which are grown in areas with high pollution and consumed as food, is very important. In the present study, it was aimed to determine the change of Ba concentration by species and organ in several fruits grown in areas with high traffic density.

Within the scope of this study, Ba concentrations in leaf, branch, bark, seed, and fruits of Prunus ceresifera, Tilia tomentosa, Prunus avium, and Prunus cerasus were compared. As a result, it was determined that the change of Ba concentrations by species and the change by organ were statistically significant in all organs and in all species, respectively. In general, the lowest values were found in Prunus cerasus or Prunus avium, whereas the highest values were observed in Tilia tomentosa. Considering the organs, the lowest values were found in seed and the highest ones in bark and branch.
\end{abstract}

Keywords: Barium; Ba; Heavy metal; Fruit

\section{Introduction}

Nowadays, many of the most important problems throughout the world are those related with the increasing population $[1,2]$. The growing population also brings numerous problems $[3,4]$. Food deficiency is one of these problems and it was reported that approx. 830 million people throughout the world have chronic hunger [5]. It is estimated that the food supply, which has doubled in the last 35 years in order to meet the continuously increasing food demand, will double again in the next 15 years. With this increase, the areas allocated to herbal production and animal husbandry will gradually shrink and they will lose their quality [6].

It is tried to solve the food problem by using different methods such as determining the new areas to produce food products and usage areas, which have not been used for food production. Within this context, one of the methods coming to the forefront in recent years is the production of food products in urban areas. It is recommended to grow plants,

\footnotetext{
${ }^{*}$ Corresponding author: Halil Baris Ozel

Bartin University; Faculty of Forestry; Forest Engineering Department, Bartin, Türkiye.

Copyright (C) 2021 Author(s) retain the copyright of this article. This article is published under the terms of the Creative Commons Attribution Liscense 4.0.
} 
which can be consumed as food, in all the urban regions that are suitable for growing plant [5]. However, previous studies showed that the pollution of air [7-9], water [10,11], and soil [12-14] in urban areas are at very high levels.

Studies revealed that heavy metal pollution, especially the traffic-related pollution, is at a very high level [15-17]. Heavy metals are the elements that can remain in nature without any degradation and do not disappear very easily and some of them can be toxic, carcinogenic, and lethal for humans even at low concentrations [18-20]. Previous studies showed that the heavy metal concentrations of the plants grown in city centers [21,22]. Hence, determining the heavy metal concentrations in plants, which are grown in city centers and consumed as food, is of critical importance for human health.

Barium (Ba), which is one of the important heavy metals, is an element playing important role in production of many products. Barium, its isotopes, compounds, and alloys are used in production of $\mathrm{Zn}, \mathrm{Pb}, \mathrm{Ag}$, rubber, ink, brake pad base, dye, rat poison, medication, radio vacuum tube and lamps, machine oil, optic glass, bromide paper, detergents, candle, plastic and textile products, drilling practices, glue, paper coatings, batteries, special glasses, oil color, oil industry, fireworks, and ceramic glazes. However, $\mathrm{Ba}$ is one of the most dangerous heavy metals and all of the barium compounds are toxic [23]. Hence, determining the Ba concentration in plants that are consumed as food is very important. In the present study, it was aimed to determine the Ba concentration in several plants, which are grown in high-traffic regions and consumed as food.

\section{Material and methods}

The present study was carried out on Prunus ceresifera, Tilia tomentosa, Prunus avium, and Prunus cerasus, which are widely grown in city centers and consumed as food. Within the scope of this study, branches with fruits on them were collected from the individuals, which were grown in high-traffic regions, at the end of June. Then, the branch samples were divided into organs (leaf, branch, bark, seed, and fruit) in the laboratory and then the samples were dried at room temperature for 15 days. Then, the samples were dried in drying oven at $50^{\circ} \mathrm{C}$ for a week. The prepared samples were ground into powder and the samples weighed at $0.5 \mathrm{~g}$ were taken into tubes prepared for microwave. Then, the samples added with $10 \mathrm{~mL} 65 \% \mathrm{HNO}_{3}$ were combusted in a microwave under 280 PSI pressure and at $180^{\circ} \mathrm{C}$ for 20 minutes. After the procedures, the tubes were taken out of the microwave and left for cooling. The cooled samples were added with deionized water up to $50 \mathrm{~mL}$. The samples were filtered through filter paper and then read at the appropriate wavelength using an ICP-OES device. This method has been widely used in many studies in determining the heavy metals in plants [24-27].

The data were analyzed using variance analysis in SPSS package program and the factors with a statistically significant difference at the minimum confidence level of $95 \%$ were subjected to Duncan's test. The data obtained were interpreted by simplifying and tabularizing.

\section{Results}

Duncan test results, mean values, error ratio, and $\mathrm{F}$ values obtained from the variance analysis of the changes of $\mathrm{Ba}$ concentrations in organs by species are presented in Table 1.

Table 1 Change of Ba (ppb) concentration by species

\begin{tabular}{|c|c|c|c|c|c|}
\hline Organ & Prunus ceresifera & Prunus cerasus & Prunus avium & Tilia tomentosa & F Value \\
\hline Leaf & $16.64 \mathrm{~b}$ & $8.41 \mathrm{a}$ & $8.02 \mathrm{a}$ & $15.66 \mathrm{~b}$ & $96.354^{* * *}$ \\
\hline Branch & $15.57 \mathrm{~b}$ & $11.41 \mathrm{a}$ & $20.15 \mathrm{c}$ & $24.67 \mathrm{~d}$ & $3661.598^{* * *}$ \\
\hline Bark & $16.91 \mathrm{c}$ & $13.02 \mathrm{~b}$ & $12.78 \mathrm{a}$ & $18.13 \mathrm{~d}$ & $2730.543^{* * *}$ \\
\hline Seed & $3.92 \mathrm{c}$ & $2.50 \mathrm{~b}$ & $2.32 \mathrm{a}$ & $8.26 \mathrm{~d}$ & $3403.911^{* * *}$ \\
\hline Wood & $5.14 \mathrm{c}$ & $22.80 \mathrm{~d}$ & $4.10 \mathrm{~b}$ & $3.42 \mathrm{a}$ & $128599^{* * *}$ \\
\hline Fruit & $4.67 \mathrm{~b}$ & $3.00 \mathrm{a}$ & $4.58 \mathrm{~b}$ & - & $980.259^{* * *}$ \\
\hline
\end{tabular}

As seen in Table 1, the change of Ba concentration by species was statistically significant for all organs ( $<<0.001)$. Given the mean values and Duncan's test results, it can be seen that the data gathered in two groups for leaf and fruit, whereas 
they constitute a separate group for the other organs. The lowest value in wood was found in Tilia tomentosa, whereas the lowest values in other organs were found in Prunus cerasus or Prunus avium. The highest values in organs other than wood were generally found in Tilia tomentosa.

Duncan test results, mean values, error ratio, and F values obtained from the variance analysis of the changes of Ba concentrations in species by organs are presented in Table 2.

Table 2 Change of $\mathrm{Ba}(\mathrm{ppb})$ concentrations by organs

\begin{tabular}{|l|c|c|c|c|}
\hline Organ & Prunus ceresifera & Prunus cerasus & Prunus avium & Tilia tomentosa \\
\hline Leaf & $16.64 \mathrm{e}$ & $8.41 \mathrm{c}$ & $8.02 \mathrm{~d}$ & $15.66 \mathrm{c}$ \\
\hline Branch & $15.57 \mathrm{~d}$ & $11.41 \mathrm{~d}$ & $20.15 \mathrm{f}$ & $24.67 \mathrm{e}$ \\
\hline Bark & $16.91 \mathrm{f}$ & $13.02 \mathrm{e}$ & $12.78 \mathrm{e}$ & $18.13 \mathrm{~d}$ \\
\hline Seed & $3.92 \mathrm{a}$ & $2.50 \mathrm{a}$ & $2.32 \mathrm{a}$ & $8.26 \mathrm{~b}$ \\
\hline Wood & $5.14 \mathrm{c}$ & $22.80 \mathrm{f}$ & $4.10 \mathrm{~b}$ & $3.42 \mathrm{a}$ \\
\hline Fruit & $4.67 \mathrm{~b}$ & $3.00 \mathrm{~b}$ & $4.58 \mathrm{c}$ & - \\
\hline F Value & $10141.309^{* * *}$ & $43402.503^{* * *}$ & $2026.897^{* * *}$ & $450.298^{* * *}$ \\
\hline
\end{tabular}

Examining Table 2, it can be seen that the change of Ba concentration by organs was statistically significant for all the species examined in the present study $(\mathrm{p}<0.001)$. Given the mean values and Duncan's test results, the lowest value of Tilia tomentosa was found in wood, whereas the lowest values were found in seed in all other species. The highest values were found in bark in Prunus ceresifera, in wood in Prunus cerasus, and in branch in Prunus avium and Tilia tomentosa.

\section{Discussion}

Within the scope of this study, it was determined that the change of Ba concentration by species was statistically significant in all the organs. In many studies carried out before, it was revealed that the concentration changes of many elements by species were statistically significant $[28,29]$. and the most important factor influencing the element concentration in plants by organ was the plant species [30].

The accumulation of elements in organs within the plant organism is shaped by the mutual interaction between many factors [31]. One of the most important factors is the habitus and development of plant [32-34]. Plant development is affected by the mutual interaction between genetic structure [35-38] and environmental conditions [39-42]. Since the genetic structure of plants significantly varies between the species, it is usual for the accumulation of heavy metal in the same organs of different species grown in the same environment to be different and it was reported in many studies $[15,16]$.

Another factor influencing the heavy metal accumulation in plants is the habitus of plant [27]. Besides the plant's genetic structure, plant habitus is affected by the climatic factors such as temperature, precipitation, and humidity [43-47] and edaphic factors such as soil texture, structure, nutrient content, and $\mathrm{pH}$ [48-52]. Hence, habitus and genetic structure of plants are affected by many factors that are in mutual interaction with each other [53]. Thus, it is usual for the heavy metal accumulation in the same organs of different species to be at different levels.

As a result of this study, it was determined that the change of Ba concentration by organs was statistically significant for all species; in general, the lowest values were found in seeds and the highest ones in barks and branches. It was reported in many studies that the heavy metal accumulations in different organs were at different levels. The accumulation of heavy metals in organs is influenced by the mutual interaction between many factors and the organ structure is among the most important factors [24,25].

Heavy metals can enter the plant body through soil or air. Especially in the intakes from air, the duration of interaction with air is very important. The seeds, in which the lowest concentrations were found in the present study, are within the fruit and they have no contact with air. However, bark and wood are always in contact with air. Furthermore, in the regions with high pollution levels, the heavy metals in the air adhere to the particles and contaminate them with heavy 
metal. Because of the rough structure of bark, the particles contaminated with heavy metal can easily retain on the bark surface and the heavy metal concentration in bark increases [21]. Especially in previous studies comparing the heavy metal concentrations in outer bark and wood, it was determined that the heavy metal concentrations in outer bark were much higher than in the wood [26,27].

Heavy metal accumulation in various organs of plants is closely related with the plant metabolism. For this reason, various factors significantly affecting the plant metabolism such as stress level [54-56], hormone treatments [57-59], and cultivation practices such as pruning and shading [60] also affect the heavy metal accumulation within the plants. Moreover, the environment and soil structure changing with the human effect in urban areas and also the microecological factors emerging as a result of human effects [61-65] can influence the change of elements in plant organs.

As a result of this study, it was determined that Ba concentration can be at very high levels in fruits of several species grown in urban areas. Similar results were reported in some of the studies carried out on this subject. For instance, in a study carried out on plum, the highest Ni concentration was obtained from the fruits [5]. Besides the toxic effects of metals on plants, the food security also drew interest throughout the world in recent years. Many studies have been carried out on the health risks related with the consumption of contaminated vegetables in the last 20-30 years and it was reported that heavy metal contents in the edible plants grown in polluted regions can cause severe public health problems by exceeding the maximum acceptable limit $[5,66]$. Hence, consumption of various organs of plants, which are grown in high-traffic regions, as food may cause severe health problems.

\section{Suggestions}

Within the scope of this study, the changes of $\mathrm{Ba}$, which is one of the heavy metals that are very toxic and can pose significant risk for human health despite they are widely used, in the organs of four plant species widely grown in city centers were examined. Heavy metals are very dangerous elements for human health and some of them may have a toxic effect even at very low concentrations. Hence, determining the concentrations of these elements in organs, which are consumed as food and thus directly taken into the human body, is very important for human health.

Consumption of foods contaminated by heavy metals is very dangerous for human health. For this reason, consumption of plants grown in highly polluted areas such as mining facilities, industrial facilities, and high traffic density is very risky for health and citizens and authorized bodies should be informed about the risks of consuming these plants as food.

Within the scope of this study, four plant species were examined. However, many vegetables and fruits are grown in regions with high levels of heavy metal pollution and they are sometimes consumed as food. Furthermore, agricultural activities are conducted in large areas nearby several industrial facilities. It is very important to examine these plants and to reveal the potential threats in further studies. Hence, it is recommended to carry out similar studies by increasing the diversity.

\section{Conclusion}

Air pollution is one of the most important problems threatening the organic life and ecosystem throughout the world. Among the components of air pollution, the most important ones are the heavy metals that can be toxic and carcinogenic even at low concentrations and even the nutrient elements can be harmful when at high concentrations. However, edible landscaping poses a considerable risk. Heavy metal accumulation in plants grown in urban centers can reach to high levels, and consuming these plants will allow these heavy metals a direct access into the human body and wreak havoc to the public health. But since this subject has not been sufficiently studied yet, the extent of such a risk is not accurately determined yet. This study aims to determine the changes of Ba concentrations in the leaves, branches, barks, seeds, fruits and woods of Prunus ceresifera, Tilia tomentosa, Prunus avium, and Prunus cerasus. The results showed that the concentrations of Ba element increased in many organs and that the heavy metal concentrations in fruits could be very high. This situation indicates that fruit and vegetables grown in urban centers, where heavy metal pollution may be high, can be harmful to the public health if consumed as crops. Although a large number of plant species have been the subject of studies to date, these studies are not at a sufficient level yet. Therefore, it can be recommended to continue and diversify similar studies. 


\section{Compliance with ethical standards}

\section{Acknowledgments}

We thanks to Bartin University, Faculty of Forestry and Kastamonu University, Faculty of Architecture and Engineering.

\section{Disclosure of conflict of interest}

The authors declare that they no conflict of interest. The none of the authors have any competing interests in the manuscript.

\section{References}

[1] Kilicoglu C, Cetin M, Aricak B, Sevik H. Site selection by using the multi-criteria technique-a case study of Bafra, Turkey. Environmental Monitoring and Assessment. 2020; 192(9): 1-12.

[2] Cetin M, Onac AK, Sevik H, Canturk U, Akpinar H. Chronicles and geoheritage of the ancient Roman city of Pompeiopolis: a landscape plan. Arabian Journal of Geosciences. 2018; 11(24): 1-12.

[3] Bayraktar OY, Saglam-Citoglu G, Abo Aisha AES. Performance research of lime based mortars. International Journal of Trend in Research and Development. 2019; 6(1): 257-259.

[4] Bayraktar OY. The Use of Rice Husk Waste in Foam Concrete Production. Turkish Journal of Agriculture-Food Science and Technology. 2020; 8(12): 2716-2722.

[5] Sevik H, Cetin M, Ozel HB, Ozel S, Cetin IZ. Changes in heavy metal accumulation in some edible landscape plants depending on traffic density. Environmental Monitoring and Assessment. 2020; 192(2): 78.

[6] Dölekoğlu CÖ, Yurdakul O. Adana ilinde hane halkının beslenme düzeyleri ve etkili faktörlerin logit analizi ile belirlenmesi. Akdeniz University Faculty of Economics \& Administrative Sciences Faculty Journal. 2004; 4(8).

[7] Isinkaralar K, Cetin M, Icen HB, Sevik H. Indoor Quality Analysis of CO2 For Student Living Areas. In: The International Conference on Science, Ecology and Technology I (ICONSETE'2015) August 25- 28, 2015, Vienna, Austria. 2015; 123.

[8] Aricak B, Cetin M, Erdem R, Sevik H, Cometen H. The change of some heavy metal concentrations in Scotch pine (Pinus sylvestris) depending on traffic density, organelle and washing. Applied Ecology and Environmental Research. 2019; 17(3): 6723-6734.

[9] Elsunousi AAM, Sevik H, Cetin M, Ozel HB, Ucun Ozel H. Periodical and regional change of particulate matter and CO2 concentration in Misurata. Environ Monit Assess. 2021; $193: 707$.

[10] Ucun Ozel H, Ozel HB, Cetin M, Sevik H, Gemici BT, Varol T. Base alteration of some heavy metal concentrations on local and seasonal in Bartin River. Environmental monitoring and assessment. 2019; 191(9): 594.

[11] Ucun Ozel H, Gemici BT, Gemici E, Ozel HB, Cetin M, Sevik H. Application of artificial neural networks to predict the heavy metal contamination in the Bartin River. Environmental Science and Pollution Research. 2020; 1-18.

[12] Kaplan G, Coskan U, Benli A, Bayraktar OY, Kucukbaltacı AB. The impact of natural and calcined zeolites on the mechanical and durability characteristics of glass fiber reinforced cement composites. Construction and Building Materials. 2021; 311: 125336.

[13] Kaplan G, Bayraktar OY, Memis S. Effect of high volume fly ash and micro-steel fiber on flexural toughness and durability properties in self-compacting lightweight mortar (SCLM). Construction and Building Materials. 2021; 307: 124877.

[14] Bayraktar OY, Eshtewı SST, Benli A, Kaplan G, Toklu K, Gunek F. The impact of RCA and fly ash on the mechanical and durability properties of polypropylene fibre-reinforced concrete exposed to freeze-thaw cycles and $\mathrm{MgSO} 4$ with ANN modeling. Construction and Building Materials. 2021; 313: 125508.

[15] Sevik H, Cetin M, Ozel HB, Pinar B. Determining toxic metal concentration changes in landscaping plants based on some factors. Air Quality, Atmosphere \& Health. 2019; 12(8): 983-991.

[16] Sevik H, Cetin M, Ozturk A, Ozel HB, Pinar B. Changes in $\mathrm{Pb}, \mathrm{Cr}$ and $\mathrm{Cu}$ concentrations in some bioindicators depending on traffic density on the basis of species and organs. Applied Ecology and Environmental Research. 2019; 17(6): 12843-12857. 
[17] Cetin M, Sevik H, Cobanoglu O. Ca, Cu, and Li in washed and unwashed specimens of needles, bark, and branches of the blue spruce (Picea pungens) in the city of Ankara. Environmental Science and Pollution Research. 2020; 110 .

[18] Turkyilmaz A, Sevik H, Isinkaralar K, Cetin M. Using Acer platanoides annual rings to monitor the amount of heavy metals accumulated in air. Environ Monit Assess. 2018; 190: 578.

[19] Turkyilmaz A, Sevik H, Cetin M. The use of perennial needles as bio-monitors for recently accumulated heavy metals. Landsc Ecol Eng. 2018; 14(1): 115-120.

[20] Cetin M, Sevik H, Turkyilmaz A, Isinkaralar K. Using Abies's Needles as Biomonitors of Recent Heavy Metal Accumulation. Kastamonu University Journal of Engineering and Sciences. 2021; 7(1): 1-6.

[21] Cesur A, Zeren Cetin I, Abo Aisha AES, Alrabiti OBM, Aljama AMO, Jawed AA, Cetin M, Sevik H, Ozel HB. The usability of Cupressus arizonica annual rings in monitoring the changes in heavy metal concentration in air. Environmental Science and Pollution Research (Environ Sci Pout Res). 2021.

[22] Turkyilmaz A, Cetin M, Sevik H, Isinkaralar K, Saleh EAA. Variation of heavy metal accumulation in certain landscaping plants due to traffic density. Environment, Development and Sustainability. 2020; 22(3): $2385-2398$.

[23] Aktaş S. Gümüş Endüstrisi Cevher ve Atıklarında Bazı Elementlerin ICP-OES ile Tayini. Kütahya Dumlupınar Üniversitesi Fen Bilimleri Enstitüsü Kimya Anabilim Dalı Yüksek Lisans Tezi. 82 s. 2019.

[24] Sevik H, Cetin M, Ozel HB, Akarsu H, Cetin IZ. Analyzing of usability of tree-rings as biomonitors for monitoring heavy metal accumulation in the atmosphere in urban area: a case study of cedar tree (Cedrus sp.). Environmental Monitoring and Assessment. 2020; 192(1): 23.

[25] Sevik H, Cetin M, Ozel HU, Ozel HB, Mossi MMM, Cetin IZ. Determination of Pb and Mg accumulation in some of the landscape plants in shrub forms. Environmental Science and Pollution Research. 2020; 27(2): 2423-2431.

[26] Koç İ. Using Cedrus atlantica's annual rings as a biomonitor in observing the changes of Ni and Co concentrations in the atmosphere. Environmental Science and Pollution Research. 2021; 1-7.

[27] Savas DS, Sevik H, Isinkaralar K, Turkyilmaz A, Cetin M. The potential of using Cedrus atlantica as a biomonitor in the concentrations of $\mathrm{Cr}$ and Mn. Environ Sci Pollut Res. 2021.

[28] Sevik H, Ozel HB, Cetin M, Özel HU, Erdem T. Determination of changes in heavy metal accumulation depending on plant species, plant organism, and traffic density in some landscape plants. Air Quality, Atmosphere \& Health. 2019; 12(2): 189-195.

[29] Karacocuk T, Sevik H, Isinkaralar K, Turkyilmaz A, Cetin M. The change of Cr and Mn concentrations in selected plants in Samsun city center depending on traffic density. Landscape Ecol Eng. 2021.

[30] Turkyilmaz A, Sevik H, Cetin M, Ahmaida Saleh EA. Changes in heavy metal accumulation depending on traffic density in some landscape plants. Pol J Environ Stud. 2018; 27(5): 2277-2284.

[31] Aricak B, Cetin M, Erdem R, Sevik H, Cometen H. The usability of Scotch pine (Pinus sylvestris) as a biomonitor for traffic-originated heavy metal concentrations in Turkey. Polish Journal of Environmental Studies. 2020; 29(2): 1051-1057.

[32] Ozel HB, Varol HN, Sevik H. Change of Mg concentration in several plants depending on plant species, washing status, and traffic density, World Journal of Advanced Research and Reviews. 2021; 12(01): 447-453.

[33] Ozel HB, Varol T, Emir T, Sevik H. Effects of Extraction from Compartment on Soil Enzymes. American Journal of Engineering Research. 2021; 10(2): 115-121.

[34] Canturk U, Kulaç Ş. The effects of climate change scenarios on Tilia ssp. in Turkey. Environmental monitoring and assessment. 2021; 193(12): 1-15.

[35] Güney D, Yahyaoglu Z, Bayraktar A, Atar F, Turna I. Genetic diversity of Picea orientalis (L.) Link populations in Turkey. Šumarski list. 2019; 143(11-12): 539-547.

[36] Koç İ. Examining Seed Germination Rate and Seedlings Gas Exchange Performances of Some Turkish Red Pine Provenances Under Water Stress. Düzce University Journal of Science \& Technology. 2021; 9(3): 48-60.

[37] Shults P, Nzokou P, Koc I. Nitrogen contributions of alley cropped Trifolium pratense may sustain short rotation woody crop yields on marginal lands. Nutrient Cycling in Agroecosystems. 2020; 117(2): 261-272. 
[38] Koç İ. Changes That May Occur in Temperature, Rain, and Climate Types Due to Global Climate Change: The Example of Düzce. Turkish Journal of Agriculture-Food Science and Technology. 2021; 9(8): 1545-1554.

[39] Ozkazanc NK, Ozay E, Ozel HB, Cetin M, Sevik H. The habitat, ecological life conditions, and usage characteristics of the otter (Lutra lutra L. 1758) in the Balikdami Wildlife Development Area. Environmental Monitoring and Assessment. 2019; 191(11): 645.

[40] Yucedag C, Ozel HB, Cetin M, Sevik H. Variability in morphological traits of seedlings from five Euonymus japonicus cultivars. Environmental monitoring and assessment. 2019; 191(5): 1-4.

[41] Ertugrul M, Varol T, Ozel HB, Cetin M, Sevik H. Influence of climatic factor of changes in forest fire danger and fire season length in Turkey. Environmental Monitoring and Assessment. 2021; 193(1): 1-17.

[42] Koç İ. The Effect of Global Climate Change on Some Climate Parameters and Climate Types in Bolu. Journal of Bartin Faculty of Forestry. 2021; 23(2): 706-719.

[43] Varol T, Ozel HB, Ertugrul M, Emir T, Tunay M, Cetin M, Sevik H. Prediction of soil-bearing capacity on forest roads by statistical approaches. Environmental monitoring and assessment. 2021; 193(8): 527.

[44] Varol T, Canturk U, Cetin M, Ozel HB, Sevik H. Impacts of climate change scenarios on European ash tree (Fraxinus excelsior L.) in Turkey. Forest Ecology and Management. Forest Ecology and Management. 2021; 491: 119-199.

[45] Yigit N, Mutevelli Z, Sevik H, Onat SM, Ozel HB, Cetin M, Olgun C. Identification of Some Fiber Characteristics in Rosa sp. and Nerium oleander L. Wood Grown under Different Ecological Conditions. BioResources. 2021; 16(3): 5862-5874.

[46] Kalayci Onac A, Cetin M, Sevik H, Orman P, Karci A, Gonullu Sutcuoglu G. Rethinking the campus transportation network in the scope of ecological design principles: case study of Izmir Katip Çelebi University Çiğli Campus Environmental Science and Pollution Research. 2021.

[47] Kalayci Onac A, Gönüllü Sütçüoğlu G, Karcı Demirkol A, Gündel H. Effects Of Covıd-19 Pandemıc On Preferences Of Urban Open Green Space Users. Ö. Demirel, E. Düzgüneş (Ed.), Landscape Research I (433-458). Lyon; Livre de Lyon. 2021.

[48] Kravkaz Kuscu IS, Cetin M, Yigit N, Savaci G, Sevik H. Relationship between Enzyme Activity (Urease-Catalase) and Nutrient Element in Soil Use. Polish Journal of Environmental Studies. 2018; 27(5): 2107-2112.

[49] Kravkaz-Kuscu IS, Sariyildiz T, Cetin M, Yigit N, Sevik H, Savaci G. Evaluation of the soil properties and primary forest tree species in Taskopru (Kastamonu) district. Fresenius Environmental Bulletin. 2018; 27(3): 1613-1617.

[50] Varol T, Gormus S, Cengiz S, Ozel HB, Cetin M. Determining potential planting areas in urban regions. Environmental monitoring and assessment. 2019; 191(3): 1-14.

[51] Varol T, Ertuğrul M, Özel HB, Emir T, Çetin M. The effects of rill erosion on unpaved forest road. Applied Ecology and Environmental Research. 2019; 17(1): 825-839.

[52] Yucedag C, Cetin M, Ozel HB, Aisha AESA, Alrabiti OBM, Jama AMOA. The impacts of altitude and seed pretreatments on seedling emergence of Syrian juniper (Juniperus drupacea (Labill.) Ant. et Kotschy). Ecological Processes. 2021; 10(1): 1-6.

[53] Yigit N, Cetin M, Ozturk A, Sevik H, Cetin S. Varitation of Stomatal Characteristics in Broad Leaved Species Based on Habitat. Applied Ecology and Environmental Research. 2019; 17(6): 12859-12868.

[54] Kulaç Ş, Nzokou P, Guney D, Cregg BM, Turna I. Growth and physiological response of Fraser fir [Abies fraseri (Pursh) Poir.] seedlings to water stress: seasonal and diurnal variations in photosynthetic pigments and carbohydrate concentration. HortScience. 2012; 47(10): 1512-1519.

[55] Yildiz D, Nzokou P, Deligoz A, Koc I, Genc M. Chemical and physiological responses of four Turkish red pine (Pinus brutia Ten.) provenances to cold temperature treatments. European journal of forest research. 2014; 133(5): 809-818.

[56] Koç İ, Nzokou P, Cregg B. Biomass allocation and nutrient use efficiency in response to water stress: insight from experimental manipulation of balsam fir, concolor fir and white pine transplants. New Forests. 2021; 1-19.

[57] Güney D, Bayraktar A, Atar F, Turna İ. Effects of root undercutting, fertilization and thinning on seedling growth and quality of oriental beech (Fagus orientalis Lipsky) seedlings. Artvin Çoruh Üniversitesi Orman Fakültesi Dergisi. 2020; 21(2): 214-222. 
[58] Wilson AR, Nzokou P, Güney D, Kulaç Ş. Growth response and nitrogen use physiology of Fraser fir (Abies fraseri), red pine (Pinus resinosa), and hybrid poplar under amino acid nutrition. New Forests. 2013; 44(2): 281-295.

[59] Yıldırım N, Bayraktar A, Atar F, Güney D, Öztürk M, Turna I. Effects of different genders and hormones on stem cuttings of Salix anatolica. Journal of Sustainable Forestry. 2020; 39(3): 300-308.

[60] Kulaç Ş, Yıldız Ö. Effect of Fertilization on the Morphological Development of European Hophormbeam (Ostrya carpinifolia Scop.) Seedlings. Turkish Journal of Agriculture-Food Science and Technology. 2016; 4(10): 813-821.

[61] Cetin M, Sevik H, Yigit N, Ozel HB, Aricak B, Varol T. The variable of leaf micromorphogical characters on grown in distinct climate conditions in some landscape plants. Fresenius Environmental Bulletin. 2018; 27(5): 32063211.

[62] Cetin M, Sevik H, Yigit N. Climate type-related changes in the leaf micromorphological characters of certain landscape plants. Environmental monitoring and assessment. 2018; 190(7): 404.

[63] Koç İ, Nzokou P. Do various conifers respond differently to water stress? A comparative study of white pine, concolor and balsam fir. Kastamonu University Journal of Forest Faculty. 2021.

[64] Ozel HB, Cetin M, Sevik H, Varol T, Isik B, Yaman B. The effects of base station as an electromagnetic radiation source on flower and cone yield and germination percentage in Pinus brutia Ten. Biologia Futura. 2021.

[65] Ozel HB, Abo Aisha AES, Cetin M, Sevik H, Zeren Cetin I. The effects of increased exposure time to UV-B radiation on germination and seedling development of Anatolian black pine seeds. Environ Monit Assess. 2021; 193: 388.

[66] Shaheen N, Irfan NM, Khan IN, Islam S, Islam MS, Ahmed MK. Presenceof heavy metals in fruits and vegetables: health risk implications in Bangladesh, Chemosphere. 2016; 152: 431-438. 